\title{
PERCEPATAN WAKTU PENGERJAAN PROYEK KONSTRUKSI DENGAN MENGGUNAKAN METODE FAST TRACK
}

\author{
Ahmad Fajarsyah Akhirudin ${ }^{1}$ \\ ${ }^{1}$ Pendidikan Teknik Bangunan, FT, UNJ
}

\begin{abstract}
ABSTRAK
Penelitian ini bertujuan untuk mengetahui pengaruh metode Fast Track pada pelaksanaan proyek konstruksi pada proyek pembangunan Gedung Badan Nasional Penanggulangan Bencana yang berlokasi di Jalan Pramuka Raya, Jakarta Timur. Penelitian ini dilakukan pada proyek pembangunan Gedung BNPB pada bulan September 2013 hingga Mei 2014 dengan metode survey dan wawancara. Setelah survey dan wawancara dilakukan di lokasi penelitian, data-data yang diperoleh dijadikan instrumen dalam pembuatan kuisioner yang selanjutnya diberikan kepada lima orang responden yang dianggap ahli pada bidang konstruksi. Hasil penelitian ini untuk waktu pengerjaan proyek didapat persingkatan waktu selama 21 hari dari waktu yang direncanakan, dengan penambahan biaya yang ditinjau dari segi upah pekerja sebesar Rp 197.400.000,- atau sebesar 3,4\% lebih tinggi dari biaya upah sebelum penelitian ini dilakukan dengan nilai Cost Slope Rp 9.400.000, -
\end{abstract}

Kata kunci: Fast Track, Gedung BNPB, Konstruksi

\begin{abstract}
This study aims to determine the effect of the Fast Track method on the implementation of construction projects in the construction project of the National Disaster Management Agency located on Jalan Pramuka Raya, East Jakarta. This research was conducted on the BNPB building construction project from September 2013 to May 2014 using survey and interview methods. After the survey and interviews were conducted at the research location, the data obtained were used as instruments in making questionnaires which were then given to five respondents who were considered experts in the construction sector. The results of this study for the time to work on the project obtained a shortening of time for 21 days from the planned time, with additional costs in terms of workers' wages of Rp. 197,400,000, - or 3.4\% higher than the cost of wages before this research was conducted. the value of the Cost Slope of IDR 9,400,000,-
\end{abstract}

Keywords: Fast Track, BNPB Building, Construction 


\section{PENDAHULUAN}

Salah satu tahap yang paling penting dalam keberhasilan pada pembangunan proyek konstruksi adalah perencanaan dan penjadwalan.

Perencanaan dan penjadwalan yang baik merupakan panduan untuk melaksanakan pekerjaan proyek secara efektif dan efisien. Masalah yang sering dihadapi dalam proyek konstruksi adalah terjadi ketidaktepatan antara rencana dengan realilasi pelaksanaan dalam proyek, seberapa baikpun perencanaan awal yang telah dilakukan, pada pelaksanaannya selalu terjadi perubahan yang mengakibatkan keterlambatan dalam penyelesaian. Keterlambatan suatu pekerjaan merupakan efek kombinasi dari ketergantungan antar pekerjaan dan variabilitas dalam setiap proses pekerjaan (Kasidi, 2008).

Upaya mengantisipasi keterlambatan pekerjaan diperlukan adanya pengendalian proyek yang dapat dilakukan dengan evaluasi kinerja dan waktu yang dibutuhkan untuk melakukan langkah perbaikan apabila ada perubahan dan permasalahan terhadap rencana awal.Suatusistem monitor dan pengendalian pekerjaan di samping memerlukan perencanaan yang realistis sebagai tolak ukur pencapaian sasaran, juga harus dilengkapi dengan teknik dan metode sensitif yaitu dapat segera mengungkapkan tanda-tanda apabila terjadi penyimpangan (Soeharto, 1997).

Di dalam proyek-proyek konstruksi, salah satu dari permasalahan utama di dalam perencanaan dan pengendalian jadwal adalah penentuan jadwal proyek, terutama ketika sumber daya yang diperlukan terbatas.Dalam penyusunan penjadwalan, penjadwal menggunakan suatu perkiraan waktu untuk meyakinkan penyelesaian waktu pada setiap pekerjaan atau suatu proyek.Bagaimanapun, perkiraan menggunakan metode penjadwalan tradisional sering kali gagal di dalam optimasi kinerja penjadwalan proyek yang menghasilkan sejumlah waktu yang tidak diperlukan. Sehingga berdampak kepada keterlambatan pada tiap-tiap pekerjaan yang akan mempengaruhi penyelesaian proyek secara keseluruhan.

Sejumlah evaluasi menunjukkan sebanyak $30 \%$ proyek konstruksi dibatalkan sebelum proyek tersebut selesai, karena banyaknya pemborosan waktu, biaya, dan menghabiskan usaha (effort) mereka (Leach, 2000). Kebanyakan kegagalan pembangunan proyek dikarenakan waktu dan biaya mereka melebihi rencana, pada umumnya antara 40 sampai dengan 200 persen (Robert, 2005 diacu dalam Kasidi, 2008).

Salah satu proyek yang mengalami keterlambatan waktu adalah proyek pembangunan Gedung BNPB yang dibangun oleh kontraktor PT. PP Persero yang berlokasi di Jalan Pramuka Raya, Jakarta Timur. Bangunan yang dibangun 16 lantai dengan 3 Basement dan Helipad ini dimulai pada bulan Agustus 2013 yang direncanakan selesai pada bulan Oktober 2014. Namun kenyataannya, proyek tersebut setelah berjalan hingga bulan Mei 2014, progress persentase yang sedang berjalan masih sebesar $30 \%$ sedangkan dalam perencanaan harusnya sudah mencapai $35 \%$.

Untuk mengembalikan tingkat kemajuan proyek ke rencana semula diperlukan suatu upaya percepatan durasi proyek walaupun akan diikuti meningkatnya biaya proyek. Oleh karena itu diperlukan percepatan waktu pelaksanaan proyek dengan metode Fast Track.Edwin Badrusomad (2006) menyatakan bahwa Fast Track adalah salah satu upaya mempercepat pelaksanaan proyek yang salah satu keputusannya dapat dengan menambah jumlah pekerja. Dengan diterapkannya metode ini, beberapa elemen pekerjaan pada proses konstruksi dapat dikerjakan secara bersama-sama. Pada akhirnya, hal ini menyebabkan durasi proses konstruksi secara keseluruhan dapat dipercepat.

Meninjau dari definisi Fast Track diatas, pada proyek pembangunan Gedung BNPB di Jakarta Timur, tenaga kerja yang tersedia 
sangat mencukupi untuk dilakukan Fast Track.

Dengan adanya latar belakang permasalahan tersebut, maka akan dicoba menerapkan metode Fast Track untuk mempercepat waktu pengerjaan proyek, studi kasus pada proyek pembangunan gedung BNPB di Jalan Pramuka Raya, Jakarta Timur.

\section{METODE}

Metode penelitian yang digunakan adalah Survey dan wawancara dalam pencarian data, dan Eksperimen dalam mempercepat waktu penyelesaian proyek. Dengan adanya data yang didapat dari hasil survey proyek, maka setelah data terkumpul, peneliti melakukan wawancara kepada pada sumber yang dianggap ahli untuk melakukan metode Fast Track. Salah satu data yang diperoleh dari proyek adalah kurva $S$ yang nantinya kurva $S$ ini akan dirancang ulang dengan waktu yang telah didapat dari wawancara terhadap para ahli. Hasil rancangan ulang ini akan ditinjau apakah dengan rancangan baru ini waktu pengerjaan proyek dapat dipercepat berapa lama.

Instrumen penelitian yang digunakan berupa data-data yang didapat dari survey pada objek penelitian yang kemudian dirancang ulang dengan menggunakan metode Fast Track. Selain itu juga menggunakan kuisioner yang akan digunakan dalam wawancara peneliti dengan para sumber yang di anggap ahli dalam bilang konstruksi.

\begin{tabular}{|c|c|c|c|c|c|c|}
\hline \multirow[b]{2}{*}{ No. } & \multirow[b]{2}{*}{ Item Pekerjaan } & \multirow[b]{2}{*}{$\begin{array}{c}\text { Durasi } \\
\text { (Hari) }\end{array}$} & \multirow[b]{2}{*}{$\begin{array}{c}\text { Waktu (Fast } \\
\text { Track) (Hari) }\end{array}$} & \multicolumn{2}{|c|}{ Resource } & \multirow[b]{2}{*}{ Keterangan (Metode) } \\
\hline & & & & $\begin{array}{c}\text { TK. } \\
\text { Tersedia }\end{array}$ & \begin{tabular}{|c|} 
Perlu \\
Penambahan/ \\
Tidak
\end{tabular} & \\
\hline $\mathbf{I}$ & Pekerjaan Persiapan & 420 & & 35 & & \\
\hline \multirow[t]{5}{*}{ II } & Pekerjaan Struktur & & & & & \\
\hline & Pekerjaan Pondasi & & & & & \\
\hline & Bored Pile & 75 & & 10 & & \\
\hline & Continous Pile & 60 & & 10 & & \\
\hline & Galian Tanah & 40 & & 15 & & \\
\hline \multirow[t]{2}{*}{ III } & Pekerjaan Struktur Bawah & & & & & \\
\hline & Basement 3 - Basement 1 & 120 & & 90 & & \\
\hline \multirow[t]{4}{*}{ IV } & Pekerjaan Struktur Atas & & & & & \\
\hline & Lantai 1 & 28 & & 20 & & \\
\hline & Lantai 2 - Lantai Atap & 28 & & 210 & & \\
\hline & Helipad & 21 & & 10 & & \\
\hline $\mathbf{V}$ & Pekerjaan Finishing & & & & & \\
\hline \multirow[t]{2}{*}{ VI } & Pekerjaan Finishing Exterior & & & & & \\
\hline & Tampak F - Tampak A & 90 & & 120 & & \\
\hline \multirow[t]{5}{*}{ VII } & Pekerjaan Finishing Interior & & & & & \\
\hline & Basement 3 - Basement 1 & 60 & & 60 & & \\
\hline & Lantai 1 & 90 & & 15 & & \\
\hline & Lantai 2 - Lantai Atap & 60 & & 180 & & \\
\hline & Helipad & 40 & & 5 & & \\
\hline \multirow[t]{4}{*}{ VIII } & Pekerjaan M E & & & & & \\
\hline & Mechanical & 220 & & 30 & & \\
\hline & Elektrikal & 220 & & 30 & & \\
\hline & Elektronik & 220 & & 30 & & \\
\hline $\mathbf{I X}$ & Pekerjaan Infrastruktur Halaman & 112 & & 20 & & \\
\hline
\end{tabular}




\section{HASIL DAN PEMBAHASAN}

Perbandingan hasil pengisian kuisioner 1-4

\begin{tabular}{|c|c|c|c|c|c|c|}
\hline No. & Item Pekerjaan & Dura si (Ha ri) & $\mathbf{1}$ & 2 & 3 & 4 \\
\hline I & Pekerjaan Persiapan & 420 & 399 & 399 & 399 & 399 \\
\hline \multirow[t]{5}{*}{ II } & Pekerjaan Struktur & & & & & \\
\hline & Pekerjaan Ponda si & & & & & \\
\hline & Bored Pile & 75 & 60 & & 60 & 60 \\
\hline & Continous Pile & 60 & 50 & & 50 & 50 \\
\hline & Galian Tanah & 40 & 35 & 30 & 30 & 33 \\
\hline \multirow[t]{2}{*}{ III } & Pekerjaan Struktur Bawah & & & & & \\
\hline & Basement 3 - Basement 1 & 120 & 100 & 90 & 100 & 97 \\
\hline \multirow[t]{4}{*}{ IV } & Pekerjaan Struktur Atas & & & & & \\
\hline & Lantai 1 & 28 & & & & \\
\hline & Lantai 2 - Lantai Atap & 28 & & & & \\
\hline & Helipad & 21 & & & & \\
\hline $\mathbf{V}$ & Pekerjaan Finishing & & & & & \\
\hline \multirow[t]{2}{*}{ VI } & Pekerjaan Finishing Exterior & & & & & \\
\hline & Tampak F - Tampak A & 90 & 80 & 60 & 70 & 70 \\
\hline \multirow[t]{5}{*}{ VII } & Pekerjaan Finishing Interior & & & & & \\
\hline & Basement 3 - Basement 1 & 60 & 50 & 50 & 50 & 50 \\
\hline & Lantai 1 & 90 & 70 & 80 & 75 & 75 \\
\hline & Lantai 2 - Lantai Atap & 60 & 50 & 50 & 50 & 50 \\
\hline & Helipad & 40 & 30 & 30 & 30 & 30 \\
\hline \multirow[t]{4}{*}{ VIII } & Pekerjaan M E & & & & & \\
\hline & Mechanical & 220 & 200 & 180 & 180 & 187 \\
\hline & Elektrikal & 220 & 200 & 180 & 180 & 187 \\
\hline & Elektronik & 220 & 200 & 180 & 180 & 187 \\
\hline IX & Pekerjaan Infrastruktur Hala & 112 & 90 & 80 & 80 & 84 \\
\hline
\end{tabular}

\section{Hasil Fast Track}

1. Kuisioner 1

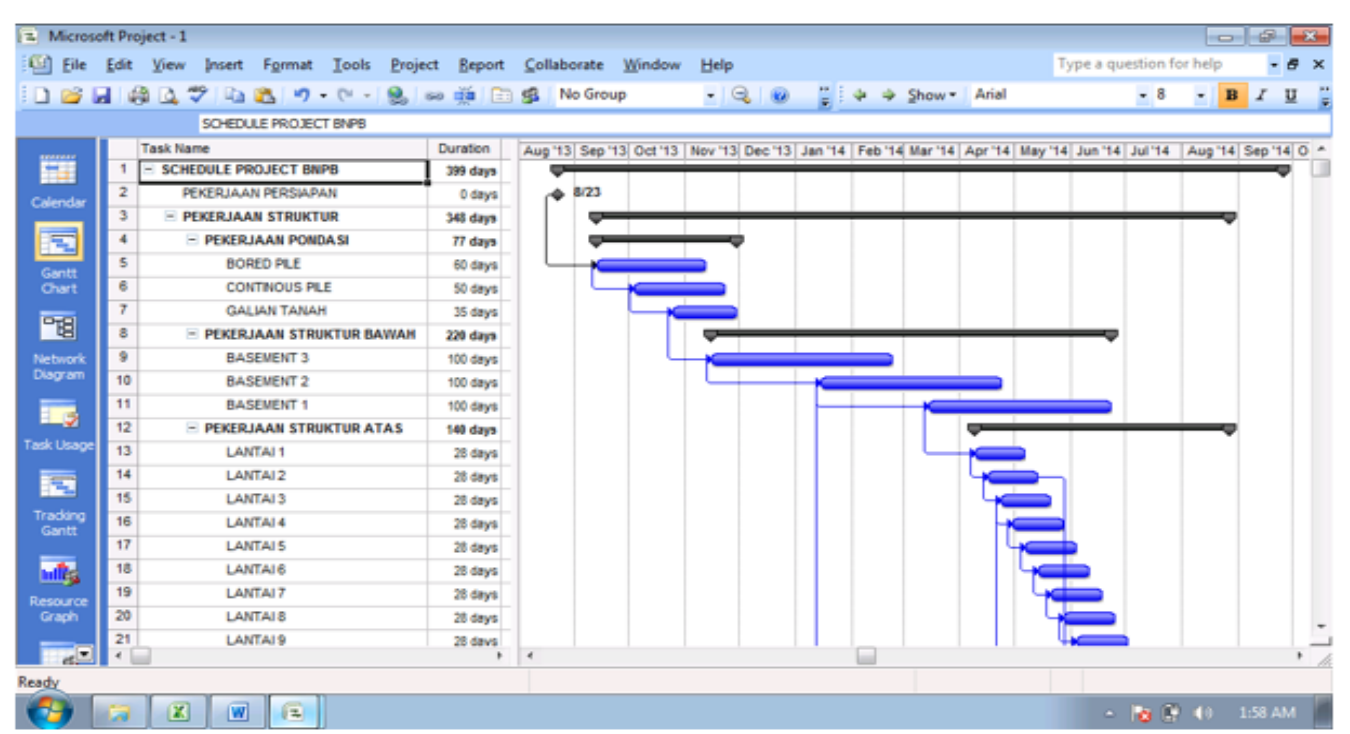

Dari kuisioner 1 didapat waktu pengerjaan proyek yang semula direncanakan selama 420 hari, dapat dikerjakan dalam waktu 399 hari. 
2. Kuisioner 2

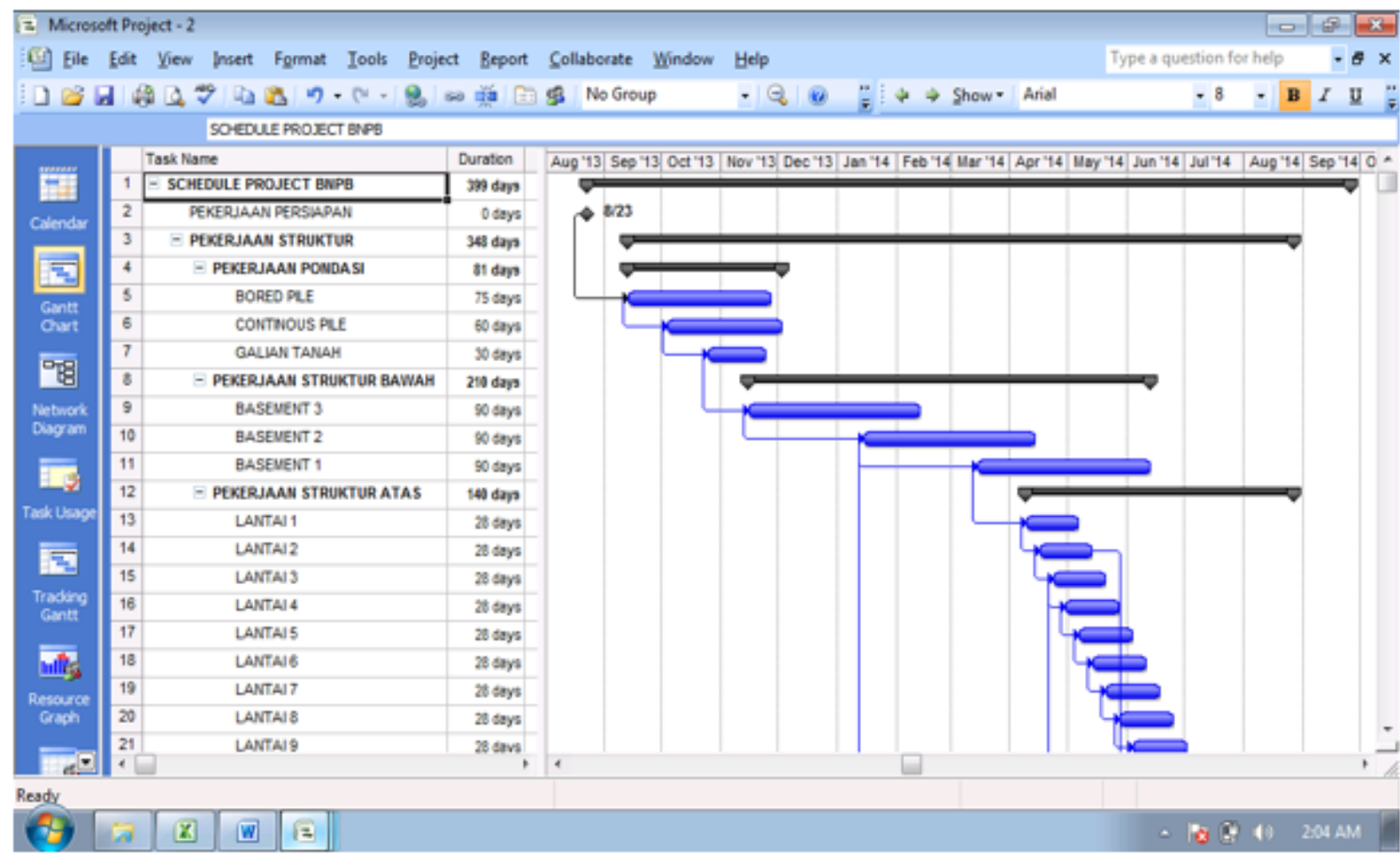

Dari kuisioner 2 didapat waktu pengerjaan proyek yang semula direncanakan selama
420 hari, dapat dikerjakan dalam waktu 399 hari.

3. Kuisioner 3

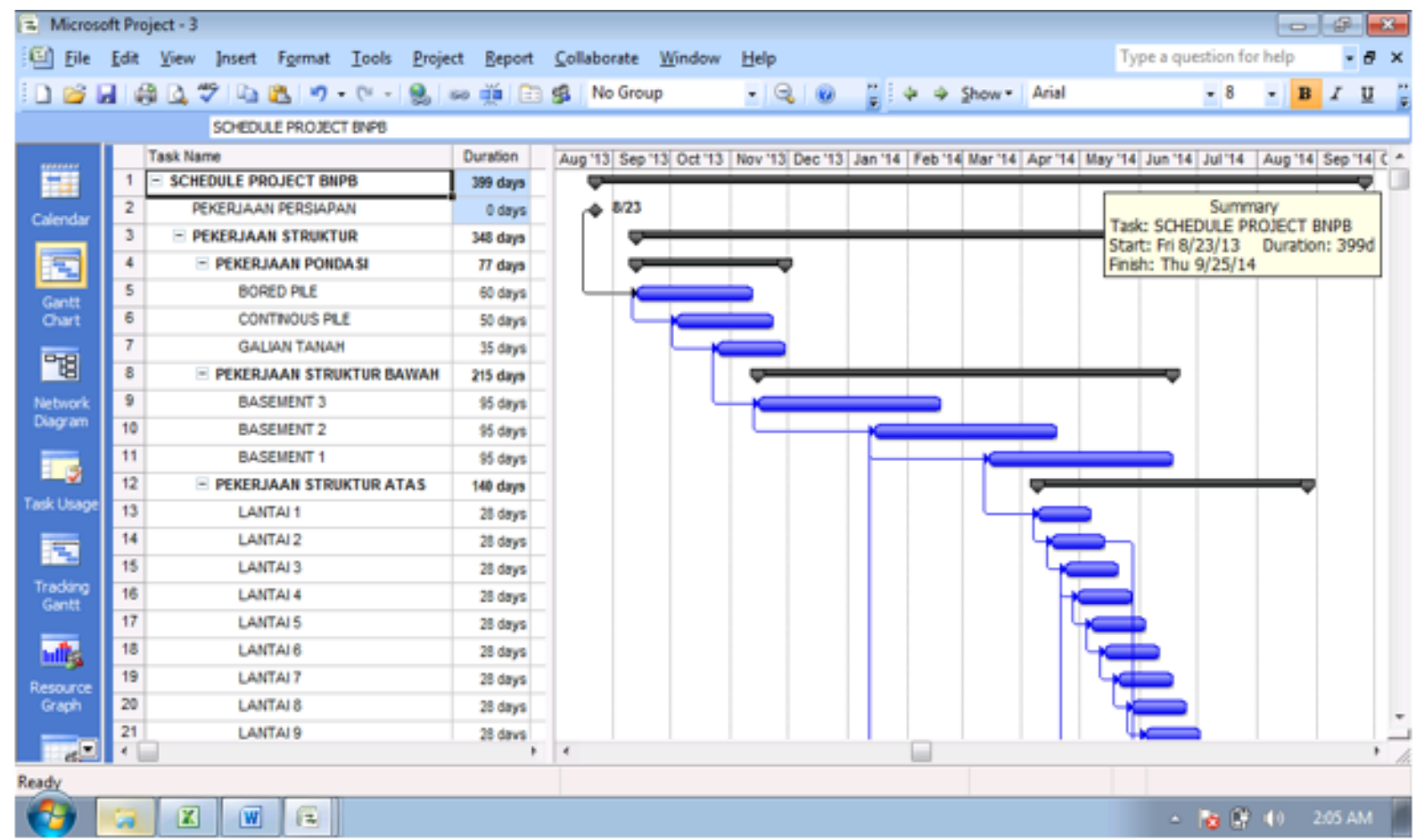


Dari kuisioner 3 didapat waktu pengerjaan proyek yang semula direncanakan selama
420 hari, dapat dikerjakan dalam waktu 399 hari.

4. Kuisioner 4

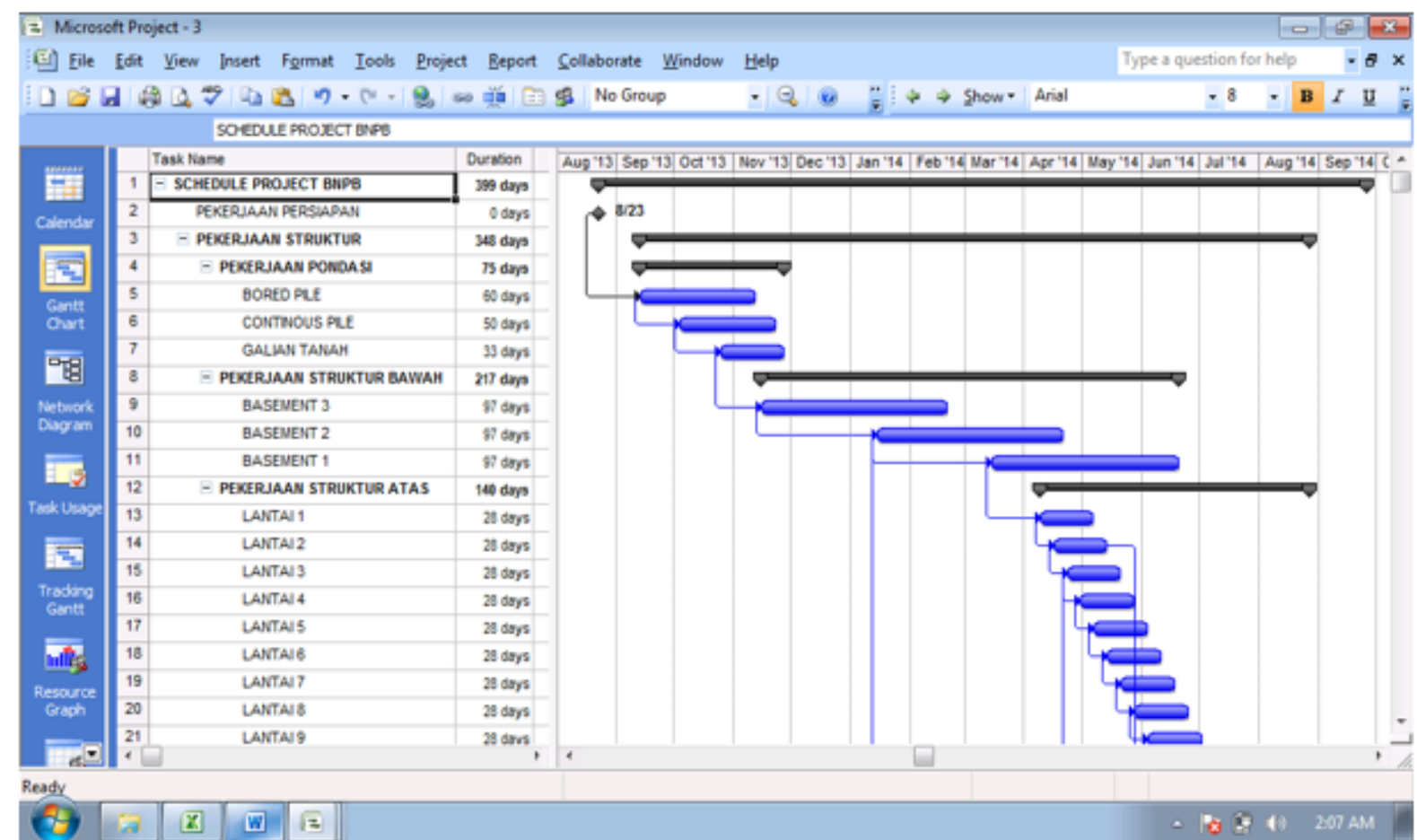

Dari kuisioner rata-rata didapat waktu pengerjaan proyek yang semula

\section{Biaya}

Biaya dihitung berdasarkan penambahan tenaga kerja pada setiap pekerjaannya.Hasil wawancara di proyek BNPB maka diketahui bahwa upah setiap tenaga kerja perhari adalah Rp. 70.000,-, sehingga sebelum dilakukan fast track, biaya yang dibutuhkan untuk upah pekerja adalah sebesar Rp. 5.802.300.000,-. direncanakan selama 420 hari, dapat dikerjakan dalam waktu 399 hari. a. Kuisioner 1

Berdasarkantabel perhitungan biaya berikut ini, dari kuisioner 1 diketahui bahwa biaya yang dibutuhkanuntuk upah pekerja adalah sebesar Rp. 6.111.700.000,-. Hal ini menujukkan bahwa terdapat penambahan biaya sebesar $5,33 \%$ atau sebesar Rp. 309.400.000,-. 
Percepatan Waktu Pengerjaan... (Ahmad/ hal. 26-34)

\begin{tabular}{|c|c|c|c|c|c|c|c|c|c|c|c|c|}
\hline \multirow{2}{*}{ No. } & \multirow{2}{*}{ Item Pek erjan } & \multicolumn{2}{|c|}{ Durasi } & \multicolumn{2}{|c|}{ Resource } & \multirow{2}{*}{ Upah Pat erja } & \multicolumn{4}{|c|}{ Biaya } & \multirow{2}{*}{\multicolumn{2}{|c|}{ Selisih Biayn }} \\
\hline & & A Amal & AN thir & TK Amal & TK Al hir & & \multicolumn{2}{|r|}{ Atual } & \multicolumn{2}{|r|}{ Althir } & & \\
\hline $\mathrm{I}$ & Pek erjan Persiapun & 420 & 399 & 35 & 40 & \multirow{25}{*}{$R p 70,000.00$} & $\mathrm{Rp}$ & $1,02,000,00000$ & $R_{p}$ & $1,117,2000,000,00$ & $R g$ & $(88,200,000,00)$ \\
\hline \multirow[t]{5}{*}{ II } & Pek erjan Strak tur & & & & & & & & & & & \\
\hline & Pek erjan Poudri & & & & & & & & & & & \\
\hline & Bored Pla & 75 & 60 & 10 & 15 & & $\mathrm{Rpg}$ & $5,500,00000$ & $\operatorname{Rp}$ & $63,000,000,00$ & $R_{p}$ & $(10,500,000.00)$ \\
\hline & Contincess Pla & 60 & 50 & 10 & 15 & & $\mathrm{Rp}$ & $42,000,00000$ & $\operatorname{Rp}$ & $52,500,000,00$ & $R_{p}$ & $(10,500,000,00)$ \\
\hline & Galign Tangh & 40 & 35 & 15 & 20 & & $\mathrm{Rp}$ & $42,000,00000$ & $R_{p}$ & $49,000,000,00$ & $R p$ & $(7,000,000,00)$ \\
\hline \multirow[t]{2}{*}{ III } & Pek erjan Strak tur Bavnh & & & & & & & & & & & \\
\hline & Bas eneat 3 -Basement 1 & 120 & 100 & 90 & 110 & & $\mathrm{Rp}$ & $756,000,000000$ & $R p$ & $770,000,900,00$ & $R g$ & $(14,000,000.00)$ \\
\hline \multirow[t]{4}{*}{ IV } & Pek erjun Struk turAtas & & & & & & & & & & & \\
\hline & Lantai 1 & 28 & & 20 & & & $\mathrm{Rp}$ & $39,200,000000$ & $R p$ & $39,200,000,00$ & $R g$ & - \\
\hline & Lantai 2- Lantai A tap & 28 & & 210 & & & $\mathrm{Rp}$ & $411,600,000000$ & $R p$ & $411,600,900,00$ & $R p$ & - \\
\hline & Helipad & 21 & & 10 & & & $R p$ & $14,700,00000$ & $R p$ & $14,700,000,00$ & $R p$ & - \\
\hline $\mathrm{v}$ & Pek erjan Fuishing & & & & & & & & & & & \\
\hline \multirow[t]{2}{*}{ VI } & Pek erjun Finishing Enteriar & & & & & & & & & & & \\
\hline & Tampak F - T mppak A & 90 & 80 & 120 & 140 & & $R p$ & $736,000,00000$ & $R p$ & $784,000,000,00$ & $R p$ & $(28,000,000.00)$ \\
\hline \multirow[t]{5}{*}{ VII } & Pek erjan Faishing Interior & & & & & & & & & & & \\
\hline & Bas ement 3 - Bas ement 1 & 60 & 50 & 60 & 80 & & $\mathrm{Rp}$ & $252,000,00000$ & $\mathrm{Rp}$ & $280,000,900,00$ & $R p$ & $(28,000,000,00)$ \\
\hline & Lantai 1 & 90 & 70 & 15 & 30 & & $\mathrm{Rp}$ & $94,500,00000$ & $\mathrm{Rp}$ & $147,000,000,00$ & $R p$ & $(52,500,000,00)$ \\
\hline & Lantai 2-Lantai Atag & 60 & 50 & 180 & 210 & & $\mathrm{Rp}$ & $736,000,00000$ & $R p$ & $735,000,900,00$ & $R p$ & $21,000,000.00$ \\
\hline & Helipad & 40 & 30 & 5 & 10 & & $\mathrm{Rp}$ & $14,000,000000$ & $R_{p}$ & $21,000,000,00$ & Rg & $(7,000,000,00)$ \\
\hline \multirow[t]{4}{*}{ IIII } & Pek erjan ME & & & & & & & & & & & \\
\hline & Mechenical & 220 & 200 & 30 & 35 & & $\mathrm{Rp}$ & $48,000,00000$ & $R p$ & $490,000,000,00$ & $R_{\rho}$ & $(28,000,000,00)$ \\
\hline & Elaterial & 220 & 2000 & 30 & 35 & & $\mathrm{Rp}$ & $48,000,00000$ & $R p$ & $490,000,900,00$ & $\mathrm{Rg}_{\rho}$ & $(28,000,000,00)$ \\
\hline & Elatron: & 200 & 200 & 30 & 35 & & $\mathrm{Rp}$ & $48,000,000000$ & $\mathrm{Rp}$ & $490,000,000,00$ & $R \rho$ & $(28,000,000.00)$ \\
\hline $\mathrm{Ix}$ & Pek erjan Infrastruk tur Halane & 112 & 90 & 20 & 25 & & $\mathrm{Rp}$ & $156,900,000000$ & $R p$ & $157,500,900000$ & $R_{g}$ & $(700,000,00)$ \\
\hline \multicolumn{7}{|c|}{$\mathrm{J} \mathrm{U} \mathrm{M} \mathrm{L} \mathrm{A} \mathrm{H}$} & & $800,300,000.00$ & $\operatorname{Rp} 6$, & $111,700,000.00$ & & $009,400,000.00]$ \\
\hline
\end{tabular}

b. Kuisioner 2

Berdasarkan tabel perhitungan biaya dibawah ini, dari kuisioner 2 diketahui bahwa biaya yang dibutuhkan untuk upah pekerja adalah sebesar Rp. 5.999.700.000,-Hal ini menujukkan bahwa terdapat penambahan biaya sebesar 3,4\% atau sebesar Rp. 197.400.000,--

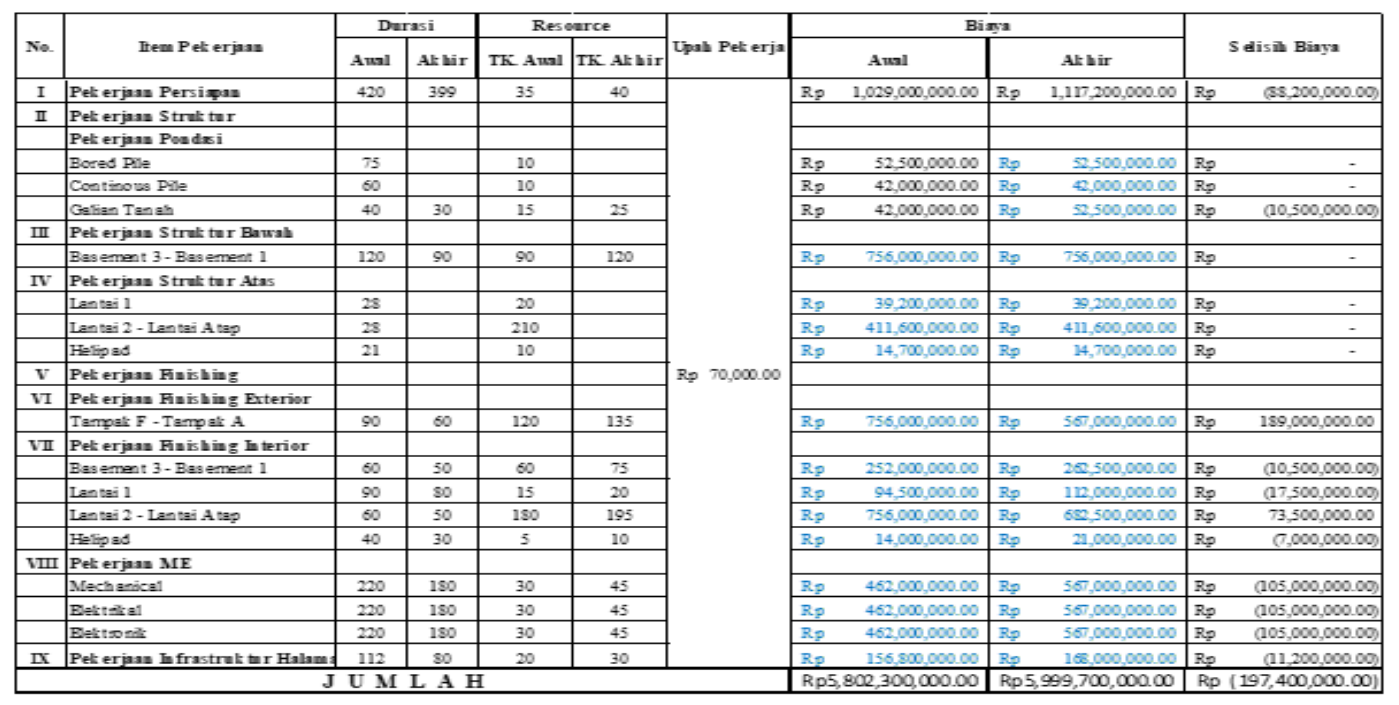


Percepatan Waktu Pengerjaan... (Ahmad/ hal. 26-34)

\begin{tabular}{|c|c|c|c|c|c|c|c|c|c|c|c|c|}
\hline \multirow{2}{*}{$\mathrm{No}$} & \multirow{2}{*}{ ItemPelcerjan } & \multicolumn{2}{|c|}{ Durai } & \multicolumn{2}{|c|}{ Resource } & \multirow{2}{*}{ Uph Pelserja } & \multicolumn{4}{|c|}{ Bima } & \multirow{2}{*}{\multicolumn{2}{|c|}{ Selisih Biagn }} \\
\hline & & Annl & Alshir & TK Amal & TK Allwir & & \multicolumn{2}{|r|}{ Annl } & \multicolumn{2}{|r|}{ Alshir } & & \\
\hline I & Pelserjaan Persinpan & 420 & 399 & 35 & 42 & \multirow{25}{*}{$R p 70,000,00$} & $\mathrm{Bp}$ & $1,029,000,000,00$ & $\mathrm{Bp}$ & $1,173,060,000,00$ & $R p$ & $(144,060,000,00$ \\
\hline \multirow{5}{*}{ II } & Pelkerjaan Strultur & & & & & & & & & & & \\
\hline & Pelserjaan Poudnsi & & & & & & & & & & & \\
\hline & Bored Pile & 75 & 60 & 10 & 15 & & $\mathrm{Bp}$ & $52,500,000,00$ & $R p$ & $63,000,000,00$ & $R p$ & $(10,500,000,00$ \\
\hline & Continous Pile & 60 & 50 & 10 & 15 & & $\mathrm{Rpp}$ & $42,000,000,00$ & $R p$ & $52,500,000,00$ & $\mathrm{Rp}$ & $(10,500,000,00$ \\
\hline & Galian Tamah & 40 & 33 & 15 & 23 & & $\mathrm{Bp}$ & $42,000,000,00$ & $\mathrm{Rp}$ & $53,130,000,00$ & $R p$ & $(11,130,000,00$ \\
\hline \multirow[t]{2}{*}{ III } & Pelserjaan Strulttur Banah & & & & & & & & & & & \\
\hline & Basement 3-Basenent 1 & 120 & 97 & 90 & 117 & & $\mathrm{Bp}$ & $756,000,000,00$ & $R p$ & $794,430,000,00$ & $R p$ & $(38,430,000,00$ \\
\hline \multirow[t]{4}{*}{ IV } & Pelserjann Strulttur Ata & & & & & & & & & & & \\
\hline & Lantai 1 & 28 & & 20 & & & $\mathrm{Bp}$ & $39,200,000,00$ & $R p$ & $39,200,000,00$ & $R p$ & - \\
\hline & Iantai 2-Iantai Atap & 28 & & 210 & & & $\mathrm{Bp}$ & $411,600,000,00$ & $R p$ & $411,600,000,00$ & $R p$ & - \\
\hline & Helipad & 21 & & 10 & & & Rpp & $14,700,000,00$ & $R p$ & $14,700,000,00$ & $\mathrm{Rp}$ & - \\
\hline $\mathrm{v}$ & Pelkerjaan Finishing & & & & & & & & & & & \\
\hline \multirow[t]{2}{*}{ VI } & Pelkerjann Finishing Exterior & & & & & & & & & & & \\
\hline & TampakF - TampakA & 90 & 70 & 120 & 142 & & $\mathrm{Bp}$ & $756,000,000,00$ & $R p$ & $05,800,000,00$ & $\mathrm{Rp}$ & $60,200,000,00$ \\
\hline \multirow[t]{5}{*}{ VII } & Pelserjann Finishing Interior & & & & & & & & & & & \\
\hline & Basement 3-Basenent 1 & 60 & 50 & 60 & 75 & & $\mathrm{Rp}$ & $252,000,000,00$ & $\operatorname{Rp}$ & $262,500,000,00$ & $\mathrm{Rp}$ & $(10,500,000,00$ \\
\hline & Iantai 1 & 90 & 75 & 15 & 23 & & $\mathrm{Bp}$ & $94,500,000,00$ & $R p$ & $20,750,000,00$ & $R p$ & $(26,250,000,00$ \\
\hline & Iantai 2-Iantai Atap & 60 & 50 & 180 & 202 & & $\mathrm{Rpp}$ & $756,000,000,00$ & $R p$ & $707,000,000,00$ & $\mathrm{Rp}$ & $49,000,000,00$ \\
\hline & Helipad & 40 & 30 & 5 & 9 & & $\mathrm{Bp}$ & $14,000,000,00$ & $R p$ & $18,900,000,00$ & $R p$ & $(4,900,000,00$ \\
\hline \multirow[t]{4}{*}{ IIII } & I PelkerjaanME & & & & & & & & & & & \\
\hline & Mechanial & 220 & 187 & 30 & 40 & & $\mathrm{Bp}$ & $462,000,000,00$ & $R p$ & $523,600,000,00$ & $\mathrm{Rp}$ & $(61,600,000,00$ \\
\hline & Elaitrival & 220 & 187 & 30 & 40 & & $\mathrm{Rp}$ & $462,000,000,00$ & $R p$ & $523,600,000,00$ & $R p$ & $(61,600,000,00$ \\
\hline & Eleitronik: & 220 & 187 & 30 & 40 & & Rp̣ & $462,000,000,00$ & $R p$ & $523,600,000,00$ & $R p$ & $(61,600,000,00$ \\
\hline $\mathbf{X}$ & Pelseriann Infratrultur Halm & 112 & 84 & 20 & 27 & & $\mathrm{Bo}$ & $156800,000,00$ & $R_{p}$ & $158,760,000,00$ & $R p$ & $(1,900,000,00$ \\
\hline \multicolumn{7}{|c|}{$\mathrm{J} \mathrm{U} \mathrm{M} \mathrm{L} \mathrm{A}$} & \multicolumn{2}{|c|}{ Rp5,802,300,000.00 } & \multicolumn{2}{|c|}{$\operatorname{Rp} 6,136,130,000.00$} & \multicolumn{2}{|c|}{$\operatorname{Rp}(333,830,000.00)$} \\
\hline
\end{tabular}

Perhitungan Cost Slope

Cost Slope merupakan angka perbandingan antara penambahan biaya dengan waktu yang telah di fast track.

\section{Cost Slope $=$}

\section{Accelerated Cost - Normal Cost Normal Time-Accelerated Time}

Cost Slope dari keempat data adalah sebagai berikut :

1. Kuisioner 1

$$
\begin{aligned}
\text { Cost Slope } & =\frac{6.111 .700 .000-5.802 .300}{420-399} \\
& =\frac{309.400 .000}{21} \\
& =\text { Rp. } 14.733 .333,-
\end{aligned}
$$

2. Kuisioner 2

Cost Slope $=\frac{5.999 .700 .000-5.802 .300}{420-399}$

$$
\begin{aligned}
& =\frac{197.400 .000}{21} \\
& =\text { Rp. } 9.400 .000,-
\end{aligned}
$$

3. Kuisioner 3

$$
\begin{aligned}
\text { Cost Slope } & =\frac{6.1910 .850-5.802 .300}{420-399} \\
& =\frac{389.550 .000}{21} \\
& =\text { Rp. } 18.550 .000,-
\end{aligned}
$$

4. Kuisioner Rata-rata

Cost Slope $=\frac{136.130 .000-5.802 .300}{420-399}$

$$
\begin{aligned}
& =\frac{333.830 .000}{21} \\
& =\text { Rp. 15.896.666,- }
\end{aligned}
$$




\section{SIMPULAN}

Berdasarkan hasil penelitian yang dilakukan, maka dapat ditarik kesimpulan sebagai berikut :

1. Metode Fast Track dapat digunakan untuk mempercepat waktu pengerjaan proyek pada proyek yang dijadikan studi kasus.

2. Dari hasil penelitian ternyata waktu proyek dapat dipercepat 21 hari.

3. Penambahan biaya yang diperlukan untuk mempercapat waktu pengerjaan proyek selama 21 hari adalah Rp. 197.400.000,- atau sebesar 3,4\% dari upah pekerja sebelum dilakukan Fast Track dengan Cost Slope sebesar Rp. 9.400.000,-.

\section{DAFTAR PUSTAKA}

Badrusomad, Edwin. 2006. Fast Track yang Efektif, Critical Path Method. http://www.edwinmdc.com Februari 2013].

Kasidi, Darwin. 2008. Penerapan Metode Critical Chain ProjectManagement pada Penjadwalan Proyek untuk Pengukuran Kinerja Waktu Proyek Konstruksi [skripsi]. Depok: Fakultas Teknik Universitas Indonesia

Leach, Lawrent P. 2000. Critical Chain Project Management. Boston: Artech House Inc

Warsika, Putu Darma. 2016. Analisa Biaya dan Waktu Dengan Metode Fast Track Pada Pelaksanaan Proyek Konstruksi (Studi Kasus : Proyek Pembangunan
Gedung di Kabupaten Badung) (Tesis). Bali : Fakultas Teknik, Universitas Udayana.

Dipohusodo, Istimawan. 1996. Manajemen Proyek \& Konstruksi - Jilid I Kanisius: Yogyakarta.

Kusnaedi, I Made. 2016. Penerapan Metode Fast Track Terhadap Efisiensi Biaya dan Efektivitas Waktu Pada Pelaksanaan Proyek Konstruksi (Studi Kasus : Proyek Hatten Wines Bali). Bali : Tugas Akhir Teknik Sipil, Fakultas Teknik, Universitas Udayana.

Tjauturono. 2008. Analisis Metode Fast Track Untuk Mereduksi Waktu dan Biaya Pelaksanaan Pembangunan Rumah Menengah di Malang.

Mardianto, Dwi. 2015. Analisis Pengaruh Metode Fast Track Pada Penjadwalan Terhadap Biaya Pelaksanaan Proyek Aapartemen Parahyangan Residences. Bandung : Tugas Akhir Teknik Sipil, Fakultas Teknik, Institut Teknologi Bandung

Soeharto, Imam. 1997. Manajemen Proyek (Dari Konseptual sampai Operasional). Jakarta: Erlangga

Tjaturono; Mochtar, Indrasurya. 2008. Pengembangan Metode Fast Track untuk Mereduksi Waktu dan Biaya

Pelaksanaan Proyek Studi Kasus Rumah Menengah di Malang, Jawa Timur. Media Komunikasi Teknik Sipil. Malang. 28 Oktober.

Soedrajat, A Sastraatmaja. 1984. Analisa (Cara Modern) Anggaran Biaya Pelaksanaan. Bandung : Nova 